\title{
Potret kesiapan guru sekolah dasar dan manajemen sekolah dalam menghadapi asesmen nasional
}

\author{
Sudianto $* 1$, Kisno ${ }^{2}$ \\ ${ }^{1}$ Sekolah Dasar Swasta Methodist Tanjung Morawa \\ Jl. Irian No. 239, Tj. Morawa Pekan, Tj. Morawa, Deli Serdang, Sumatera Utara 20362, Indonesia. \\ 2 Sekolah Tinggi Akuntansi dan Manajemen Indonesia (STAMI) \\ J1. Sutomo No. 271 \& 273, Siantar Barat, Kota Pematang Siantar, Sumatera Utara 21145, Indonesia. \\ * Corresponding Author. Email: sudiantowen@gmail.com
}

\section{ARTICLE INFO}

\section{Article History}

Received:

8 March 2021;

Revised:

28 April 2021;

Accepted:

3 May 2021

Available online:

3 May 2021

\section{Keywords}

guru sekolah dasar; asesmen nasional; LOTS;

HOTS

elementary teacher; national assessment; LOTS;

HOTS.

\begin{abstract}
Kementerian Pendidikan dan Kebudayaan (Kemdikbud) menetapkan Asesmen Nasional untuk mensubtitusi Ujian Nasional. Penelitian ini bertujuan untuk memberikan gambaran sejauh mana guru-guru di sekolah dasar mempersiapkan diri mereka dalam menghadapi Asesmen Nasional, khususnya pada komponen pengetahuan mereka akan literasi membaca. Sebanyak 23 guru tersertifikasi maupun non sertifikasi dilibatkan sebagai responden. Para guru tersebut mengajar peserta didik mulai dari kelas I hingga kelas VI. Rancangan penelitian menggunakan rancangan pendekatan campuran antara kuantitatif dan kualitatif. Guru diminta untuk menjawab soal literasi membaca dan merancang soal literasi membaca mulai dari mode LOTS hingga HOTS. Hasil penelitian menunjukkan bahwa $70 \%$ guru mampu menjawab soal literasi membaca yang terdiri dari teks informasi dan teks fiksi. Guru tidak mengalami masalah dalam menyusun soal kategori LOTS, namun guru mengalami kesulitan dalam merancang soal HOTS. Kesulitan yang ditemukan adalah guru belum mampu menyusun stimulan soal secara kohesif dan koheren. Selain itu, $70 \%$ soal rancangan guru belum mencerminkan rumusan instruksi soal dengan baik sehingga menimbulkan keambiguan bagi peserta didik yang akan menyelesaikan soal-soal tersebut. Dengan demikian, sekolah menerapkan strategi penanganan khusus dengan menyelenggarakan lokakarya internal yang ditindaklanjuti dengan supervisi, monitoring, dan evaluasi secara berkala.
\end{abstract}

Education and Culture Ministry announced Nasional Assessment to replace National Exam. This study purposes to depict elementary teachers' readiness to face $\mathrm{Na}$ tional Assessment, particularly in reading literacy. There were 23 teachers involved as the participants. They, either certified or non-certified, taught students from grade 1 to grade 6. The design of the study applied mixed approaches between qualitative and quantitative study. The participants were asked to answer reading-literacy questions and construct reading-literacy questions consisting both LOTS and HOTS levels. The result showed 70\% teachers able to answer the questions consisting information and fiction texts. In other words, teachers found no problem in designing LOTS-based question, but they faced difficulty in constructing HOTS-based questions. These findings indicate teachers were not able to design cohesive and coherent texts. Besides, $70 \%$ of the questions did not meet the requirement of the wellstructured instructions which led to ambiguity for students to solve the questions. Hence, the school management stipulated a special intervention by administering internal workshop followed up by supervision, monitoring, and evaluation carried out periodically.

This is an open access article under the CC-BY-SA license.
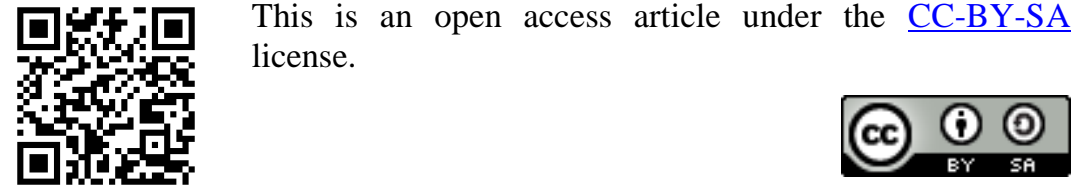

How to cite:

Sudianto, S., \& Kisno, K. (2021). Potret kesiapan guru sekolah dasar dan manajemen sekolah dalam menghadapi asesmen nasional. Jurnal Akuntabilitas Manajemen Pendidikan, 9(1), 85-97. doi:https://doi.org/10.21831/jamp.v9i1.39260 


\section{PENDAHULUAN}

Asesmen Kompetensi Minimum (AKM) sebagai salah satu bagian dari Asesmen Nasional (AN) merupakan suatu program evaluasi pendidikan berskala nasional yang dicanangkan sebagai pengganti Ujian Nasional (UN) di Indonesia. Berbagai ragam reaksi muncul dari satuan pendidikan, khususnya guru atau pendidik saat informasi mengenai Asesmen Kompetensi Minimum diedarkan oleh Kementerian Pendidikan dan Kebudayaan Republik Indonesia (Kemdikbud) sejak akhir tahun 2019 (Shara et al. (2020). Ada yang masih dalam keadaan tenang; ada yang mencoba mencaritahu bentuk pengganti Ujian Nasional tersebut; ada juga yang sudah mempersiapkan diri dalam menghadapi Asesmen Nasional. Tidak sedikit pula yang sudah sibuk mencari bimbingan belajar dalam menghadapi Asesmen Nasional yang direncakan akan dilaksanakan pada bulan Maret hingga April tahun 2021 sesuai masingmasing jadwal tingkat satuan pendidikan. Padahal, masih banyak guru yang menyamakan Asesmen Nasional dengan Ujian Nasional, sehingga menimbulkan miskonsepsi pada substansi keduanya (Kisno et al., 2021a).

Asesmen Kompetensi Minimum menitikberatkan pada dua aspek kompetensi dasar, yakni literasi membaca dan literasi numerasi dan bukan lagi hanya sekadar pemahaman dan capaian pada kurikulum atau mata pelajaran (Muta'ali, 2020). Selain itu, ada juga yang beranggapan bahwa Asesmen Nasional mengadaptasi jenis dan bentuk soal PISA (Program for International Students Assessment), yaitu suatu program yang menilai kemampuan siswa berskala internasional. Bila dikaitkan dengan capaian peserta didik Indonesia pada hasil PISA 2018, Indonesia menempati posisi 10 besar terbawah dibandingkan capaian rata-rata 79 negara yang mengikuti asesmen tersebut (Ningsih et al., 2021). Ironisnya, skor capaian Indonesia dalam tiga komponen asesmen PISA yakni literasi membaca, literasi matematika, dan literasi sains cenderung menunjukkan penurunan dibandingkan hasil yang dicapai pada tahun 2015, padahal pemerintah melalui Kemdikbud telah menetapkan Undang-Undang No. 23 Tahun 2015 mengenai Gerakan Literasi Nasional melalui penumbuhan budi pekerti.

Bercermin dari keadaan, ini, pemerintah terus melakukan perubahan dan perbaikan khususnya dalam peningkatan mutu pendidikan nasional. Program-program yang digalakkan pemerintah antara lain adalah dengan meneruskan Gerakan Literasi Nasional, melakukan kajian akademik, membuat kerangka asesmen dan prototipe tes, penyusunan soal, dan pembentukan tim teknis di tiap daerah. Selain itu, pemerintah juga melakukan pemetaan dan perecanaan kebutuhan TIK, pelatihan tim teknis, simulasi infrastruktur skala kecil, hingga melakukan ujicoba berskala besar. Tidak ketinggalan pula, sosialisasi Asesmen Nasional ke seluruh satuan pendidikan hingga ke daerah, pelatihan pemahaman Asesmen Kompetensi Minimum dilakukan kepada satuan pendidikan dan kepada guru-guru di seluruh Indonesia secara bertahap. Belakangan ini, Menteri Pendidikan dan Kebudayaan Republik Indonesia megumumkan bahwa pelaksanaan Asesmen Nasional diundur penyelengaraannya ke bulan September hingga Oktober 2021, karena aspirasi masyarakat untuk belajar dari rumah yang sebagai akibat dari pandemi Covid-19 yang masih berlangsung (Kementerian Pendidikan dan Kebudayaan, 2021).

Namun demikian, usaha yang telah dilakukan pemerintah tidak boleh bertepuk sebelah tangan. Satuan pendidikan harus turut serta mempersiapkan diri, khususnya bagi guru yang merupakan ujung tombak kemajuan pendidikan Indonesia. Dari observasi yang dilakukan, guru masih banyak yang belum memahami detil mengenai Asesmen Nasional, dan sebagai besar guru memiliki persepsi bahwa Asesmen Nasional identik dengan Ujian Nasional sebagai alat ukur menentukan kelulusan peserta didik. Sebagai akibat dari persepsi yang keliru ini, tidak jarang pula guru melakukan pembimbingan belajar tambahan selayaknya menghadapi Ujian Nasional. Padahal secara isi dan substansi, Asesmen Nasional dirancang untuk memantau dan mengevaluasi sistem pendidikan. Guru juga belum mengetahui secara jelas apa yang dimaksud dengan literasi membaca dan literasi numerasi. Dalam persepsi mereka, literasi membaca sama dengan kemampuan membaca sebuah teks yang disajikan dan menjawab pertanyaan-pertanyaan yang diberikan setelah membaca. Bagi mereka, literasi numerasi merupakan kemampuan menjawab soal-soal yang berhubungan dengan hitungan-hitungan matematis. Padahal, literasi membaca tidak hanya sekadar kemampuan sebatas memahami teks, namun juga menerapkan, mengevaluasi, dan merefleksikan apa yang telah dibaca agar dapat memberikan kontribusi positif kepada masyarakat, sedangkan literasi numerasi meliputi kemampuan berpikir menggunakan konsep, prosedur, fakta, dan alat matematika untuk menyelesaikan masalah sehari-hari dalam berbagai konteks yang relevan, baik untuk individu maupun masyarakat (Kementerian Pendidikan dan Kebudayaan, 2020b). 
Hasil observasi lainnya menunjukkan guru menyamakan Asesmen Kompetensi Minimum dengan Asesmen Nasional. Padahal, AKM hanya merupakan salah satu komponen dari Asesmen Nasional. Adapun komponen lainnya yang dikaji termasuk survei karakter yang diikuti oleh peserta didik dan survei lingkungan belajar yang diikuti oleh guru dan kepala sekolah dari satuan pendidikan. Dengan kata lain, guru belum sepenuhnya siap dalam memahami detil informasi mengenai Asesmen Nasional, sehingga strategi yang dilakukan tidaklah tepat. Bahkan, sebuah studi menemukan bahwa calon guru memiliki kemampuan kognitif yang rendah mengenai instrumen AKM dan banyak yang belum mengetahui rincian-rincian Asesmen Nasional (Novita et al., 2021).

Penelitian ini bertujuan memberikan gambaran sejauh mana guru-guru di sekolah dasar mempersiapkan diri mereka dalam menghadapi Asesmen Nasional, khususnya pada komponen pengetahuan mereka akan literasi membaca dan literasi numerasi. Penelitian ini diharapkan memberi kontribusi sebagai referensi bagaimana seharusnya guru mempersiapkan diri dalam memberikan strategi pembelajaran kepada peserta didik yang akan menghadapi Asesmen Nasional.

\section{METODE}

Penelitian ini dilakukan pada bulan Januari 2021 di salah satu sekolah swasta di Kabupaten Deli Serdang, Provinsi Sumatera Utara. Penelitian ini melibatkan 23 guru yang sudah maupun yang belum menerima tunjangan sertifikasi. Guru-guru tersebut mengajar peserta didik di sekolah, mulai dari kelas I hingga kelas VI.

Rancangan penelitian menggunakan rancangan pendekatan campuran antara kuantitatif dan kualitatif (mixed-method) yang bertumpu pada nilai dari kombinasi pendekatan dengan pertimbangan bahwa setiap rancangan memiliki bias dan kelemahan masing-masing. Dengan kata lain, kelemahan satu pendekatan dapat ditutupi dengan pendekatan yang lain dengan cara mengumpulkan data, baik secara kuantitatif maupun kualitatif (Creswell \& Creswell, 2018). Pada penelitian ini, data dikumpulkan dengan teknik paralel konvergen, di mana data kualitatif dan kuantitatif dikumpulkan secara terpisah, lalu dianalisis secara kombinasi dengan cara membandingkan atau mengkontraskan data, kemudian mengintegrasikan kedua hasil kombinasi data tersebut untuk menjawab rumusan masalah penelitian.

Data pengetahuan guru mengenai detil Asesmen Nasional dikumpulkan melalui instrumen berupa tes. Tes merupakan instrumen yang bertujuan untuk mengetahui capaian, mendiagnosis, atau membandingkan apakah peserta telah menguasai pengetahuan tertentu (Cohen et al., 2018). Soal-soal di dalam tes dirancang berdasarkan komponen AKM literasi membaca, yakni teks informasi dan teks fiksi yang kemudian diunggah ke Google Form. Selain itu, guru juga diminta untuk menyusun soalsoal dengan model AKM yang terdiri dari soal teks informasi dan teks fiksi. Hasil dari penyusunan butir soal dikaji secara kualitatif. Data hasil tes dianalisis secara kuantitatif dan dinarasikan sebagai penjelasan sebagai bagian dari hasil temuan, sedangkan teknik triangulasi digunakan untuk memvalidasi titik temu antara data yang diperoleh dengan rancangan campuran kualitatif dan kuantitatif.

\section{HASIL DAN PEMBAHASAN}

\section{Hasil}

Gambar 1 menunjukkan komposisi guru yang yang sudah sertifikasi dan yang belum sertifikasi. Dari 23 responden yang menjawab soal-soal literasi membaca tersebut, 44\% di antaranya sudah menerima tunjangan jabatan, sedangkan sisanya belum.

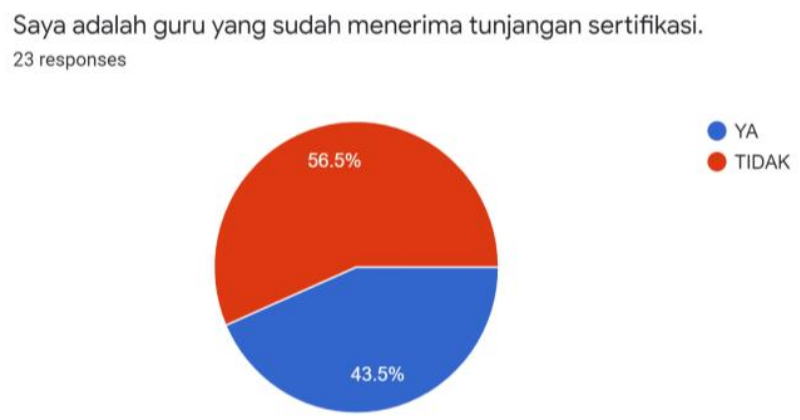

Gambar 1. Komposisi Guru Sertifikasi dan Nonsertifikasi 
Untuk mengetahui sejauh mana kesiapan guru dalam menghadapi AKM, peneliti merancang sebuah instrumen dalam bentuk tes. Pengujian sederhana dimulai dengan menyusun soal literasi membaca, yang terdiri dari lima soal literasi teks informasi dan tiga soal literasi fiksi. Soal teks pertama berupa teks informasi yang dikutip dari sebuah Webinar "Pengenalan Aplikasi Asesmen Formatif di channel Youtube Direktorat Sekolah Dasar". Pada salah satu sesi, pembicara memperkenalkan model soal AKM yang diujikan kepada siswa. Kemudian, teks berjudul Kolibri dijadikan tes untuk contoh teks informasi. Bentuk soalnya adalah pilihan ganda kompleks (Benar/Salah) sebanyak lima butir, sedangkan teks kedua berupa teks fiksi dikutip dari E-book Desain Pengembangan AKM yang diterbitkan oleh Pusmenjar halaman 47. Soal disusun dalam bentuk pilihan ganda sebanyak tiga butir. Seluruh soal, baik bacaan teks informasi maupun teks fiksi yang diambil, berada di level kognitif memahami (interpret and integrate).

Butir-butir soal kemudian dikonversi ke dalam Google Forms. Tautan diberikan secara individual kepada setiap guru dan mereka dipastikan untuk mengerjakannya secara sendiri dan mandiri di hadapan peneliti. Hasil dari menjawab soal AKM oleh guru dapat dilihat pada Tabel 1.

Tabel 1. Statistik Menjawab Soal AKM

\begin{tabular}{ccc}
\hline \multirow{2}{*}{ Guru } & \multicolumn{3}{c}{ Literasi Membaca } \\
\cline { 2 - 3 } & Lulus & Tidak Lulus \\
\hline Sertifikasi & 9 & 1 \\
Non-sertifikasi & 7 & 6 \\
Total & 16 & 7 \\
\hline
\end{tabular}

Standar kelulusan menjawab soal diukur dari guru yang berhasil menjawab pertanyaan dengan jawaban benar paling sedikit enam dari total delapan soal yang diberikan. Tabel 1 menunjukkan hampir seluruh guru tersertifikasi mampu menjawab soal tersebut dengan baik, dan satu guru yang tidak lulus tersebut hanya kekurangan satu jawaban benar untuk dinyatakan lulus. Sementara itu, perbandingan kelulusan dan ketidaklulusan guru non-sertifikasi tidak jauh berbeda, hanya selisih satu guru.

Temuan ini dengan jelas membuktikan memang benar kompetensi guru sertifikasi lebih baik ketimbang guru non-sertifikasi. Namun, temuan ini bukan merupakan sesuatu fenomena yang luar biasa sebab guru tersertifikasi memang seyogianya menunjukkan keterampilan yang lebih baik, sehingga memenuhi ekspektasi sebagai seorang guru bersertifikat pendidik. Kemudian, hal yang menarik dari temuan penelitian ini adalah terdapat satu butir soal yang paling problematik bagi sebagian besar guru, yaitu soal nomor 4. Hanya dua dari 23 guru yang mampu menjawab soal ini dengan benar, dan kedua guru tersebut bukan guru sertifikasi, dan bukan juga guru yang mengajar di kelas tinggi, yakni kelas 4, 5 , dan 6. Temuan ini mengindikasikan bahwa terdapat guru non-sertifikasi yang menguasai keterampilan membaca yang lebih baik.

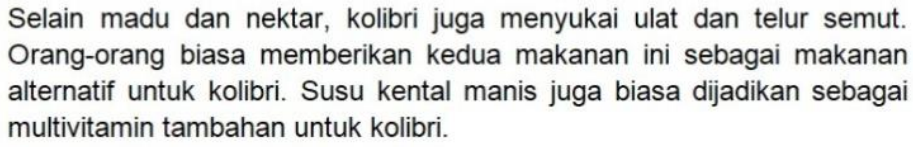

Gambar 2. Stimulan Teks Informasi

Butir pertanyaan pada Gambar 3 sama dengan 4 butir soal yang lain, yakni dengan menentukan apakah pernyataan berikut benar atau salah berdasarkan wacana yang dibaca seperti yang terdapat pada Gambar 2. Sebanyak 90\% dari seluruh guru menjawab pernyataan ini adalah benar, padahal konteks paragraf tersebut dengan jelas bukan menyebutkan mengenai tambahan makanan, tapi makanan lainnya yang disukai burung Kolibri. Selain itu, sebanyak dua butir soal lainnya (nomor 1 dan 5) yang terkait dengan teks informasi memiliki tingkat jawaban benar hanya sekitar 50\%, sedangkan hampir seluruh guru tidak menemukan kendala dalam menjawab soal butir nomor 2 dan 3 .

Guru tidak mengalami kesulitan dalam menjawab soal teks fiksi terlihat dari persentase akurasi jawaban mencapai 90\% lebih, kecuali soal pertama yang hanya berhasil dijawab oleh 17 guru. Temuan ini pun menghasilkan data menarik dan mengejutkan jika hasil kedua jenis teks tersebut dipisahkan dan dikategorikan. Setiap guru wajib memenuhi syarat kelulusan yang ditetapkan, yaitu jawabannya hanya boleh memiliki minimal paling sedikit 1 kekeliruan. 


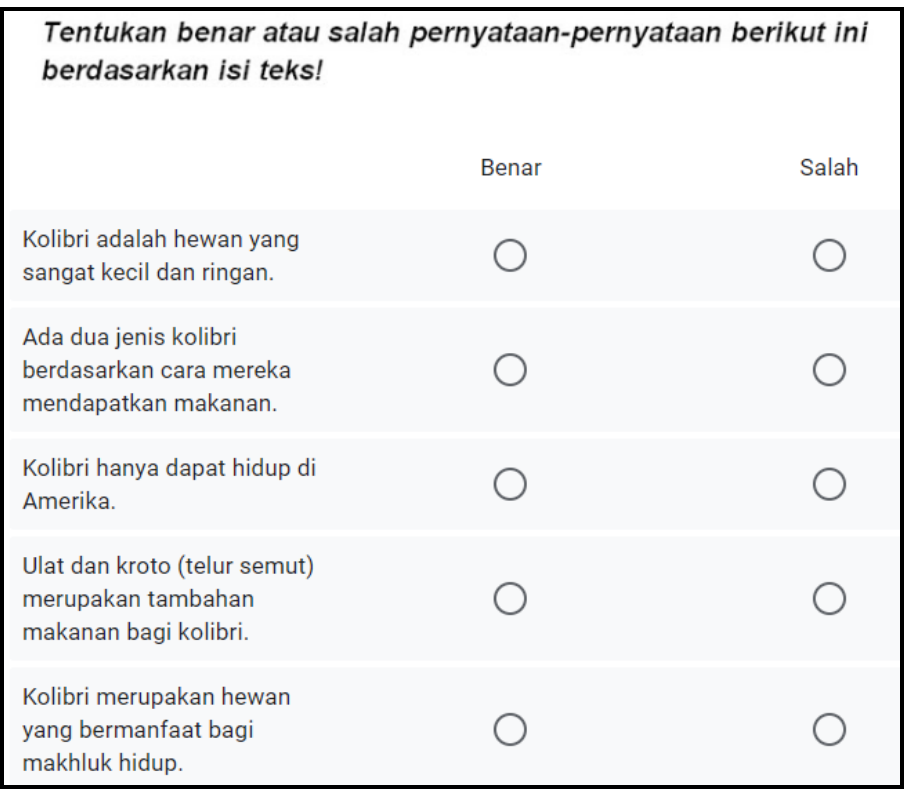

Gambar 3. Soal Teks informasi

Tabel 2. Hasil Menjawab Teks Informasi dan Teks Fiksi

\begin{tabular}{ccccc}
\hline \multirow{2}{*}{ Guru } & \multicolumn{2}{c}{ Teks Informasi*) } & \multicolumn{2}{c}{ Teks Fiksi*) } \\
\cline { 2 - 5 } & Lulus & Tidak Lulus & Lulus & Tidak Lulus \\
\hline Sertifikasi & 3 & 7 & 10 & - \\
Non-sertifikasi & 4 & 9 & 13 & - \\
Total & 7 & 16 & 23 & - \\
\hline
\end{tabular}

*) Paling sedikit 1 jawaban salah

Tabel 2 merupakan ringkasan statistik mengenai jumlah guru yang lulus dan tidak lulus dalam menjawab dua jenis teks yang akan diujikan pada AKM, yakni teks informasi dan teks fiksi. Dari data tersebut, seluruh guru mampu mengerjakan soal teks fiksi. Sebaliknya, kurang dari sepertiga jumlah seluruh guru yang mampu lulus mengerjakan soal teks informasi. Bila ditelaah lebih rinci, guru sertifikasi yang berhasil lulus sebanyak tiga orang, dan guru non-sertifikasi sebanyak empat guru. Temuan ini menunjukkan disparitas kemampuan pemahaman yang jauh antara teks informatif dan teks fiksi. Hal ini wajar karena secara leksikal, tentu teks informasi lebih rumit untuk dipahami ketimbang teks fiksi. Dengan demikian, apabila kebiasaan membaca bisa berkontribusi positif terhadap kemampuan memahami bacaan seperti yang dikonfirmasikan oleh Ayu et al. (2018), kemudian peneliti tertarik untuk menemukan gambaran sejauh mana kemampuan guru menyusun soal literasi membaca.

Pada periode Penilaian Akhir Semester tahun ajaran 2020/2021, sekolah yang menjadi objek penelitian sudah mengadopsi penyusunan model soal AKM di bidang studi tematik berdasarkan panduan yang sudah diterbitkan oleh Kemdikbud. Soal ujian tematik wajib mencantumkan dua sampai tiga teks informatif/fiksi dengan level kognitif minimal tingkat kedua hingga ketiga, yaitu memahami atau mengevaluasi dan merefleksi (Kementerian Pendidikan dan Kebudayaan, 2020b). Jumlah teks disesuaikan dengan tingkatan kelas rendah atau tinggi. Untuk jumlah butir pertanyaan bebas, guru boleh menyusun tiga sampai lima butir. Dalam proses penyusunan, setiap guru paralel kelas bebas untuk berdiskusi, bahkan mereka sangat dianjurkan untuk berkolaborasi sejak awal ketika merancang pembelajaran, hingga melaksanakan program penilaian. Dengan demikian, soal yang tersusun boleh lebih mantap dan teruji dalam penyajiannya. Tentu, semua guru juga perlu menyesuaikan dengan kompetensi dasar yang sedang diajar pada saat itu sambil juga menyesuaikannya dengan kurikulum darurat selama masa pandemi.

Selain itu, panduan langkah-langkah penyusunan soal HOTS juga diberikan kepada guru. Tahapan ini dimulai dari menentukan kompetensi dasar dan materi yang akan dinilai, menyusun kisi-kisi, merumuskan indikator soal, dan menulis soal sesuai kaidah penulisan soal (Kementerian Pendidikan dan Kebudayaan, 2019a). Dalam konteks soal model AKM, teks informatif dan fiksi termasuk ke dalam stimulus soal. Stimulus merupakan bagian kecil dari langkah ketiga dalam menulis soal HOTS 
(Kementerian Pendidikan dan Kebudayaan, 2019b). Seluruh soal diketik dalam Ms. Word, kemudian dikirimkan secara daring lewat aplikasi Whatsapp untuk diteliti dan dievaluasi sebelum dijadikan soal Penilaian Akhir Semester.

Peneliti mengkaji soal literasi membaca di bidang tematik yang disusun oleh 11 guru kelas di seluruh tingkatan dengan komposisi guru sertifikasi dan non-sertifikasi sebanyak delapan berbanding tiga. Sebagai rujukan rubrik penilaian terhadap soal yang disusun, peneliti menggunakan kaidah penulisan soal pilihan ganda dan soal dua pilihan jawaban yang diterbitkan oleh Kementerian Pendidikan dan Kebudayaan (2019a). Selanjutnya, peneliti menyisipkan dua poin mengenai penyusunan teks wacana ditinjau dari aspek kebahasaan, yaitu menggunakan kaidah Bahasa Indonesia dan memenuhi penyusunan wacana yang berkoherensi. Aspek level kognitif aplikasi atau penalaran juga ditambahkan sebagai kriteria rubric, sehingga terdapat penambahan sebanyak tiga unsur ke masing-masing kaidah.

Setiap kaidah penulisan soal mencakup aspek materi, aspek konstruksi, dan kebahasaan. Aspek materi mewajibkan guru menyusun soal harus sesuai dengan indikator dan hanya memiliki satu jawaban benar. Aspek konstruksi mengharuskan guru dapat menyusun soal dengan petunjuk yang jelas, stimulus yang berfungsi dan pilihan jawaban yang jelas, kontekstual sesuai pertanyaan soal serta tidak mengandung seluruh jawaban benar ataupun seluruh jawaban salah. Sementara itu, secara aspek kebahasaan, soal harus disusun dengan menggunakan aturan kaidah Bahasa Indonesia dan bahasa yang digunakan harus sesuai dengan tingkatan siswa yang diuji.

Penelitian dengan menggunakan rubrik sebagai evaluasi ini menemukan secara keseluruhan guru hampir tidak memiliki masalah dalam menyusun pertanyaan soal baik aspek materi, konstruksi maupun bahasa. Hanya terdapat beberapa berupa kesalahan kecil dikarenakan guru tidak terbiasa mengetik soal di komputer, sehingga terjadi kesalahan pengetikan (typo). Namun, kendala terbesar baru muncul ketika soal itu harus menggunakan stimulus soal sebagai acuan dalam memformulasikan soal sebagai ciri soal berbasiskan HOTS (Higher Order Thinking Skills) (Kementerian Pendidikan dan Kebudayaan, 2019b).

Tabel 3. Sebaran Teks Informasi dan Teks Fiksi sebagai Stimulus Soal

\begin{tabular}{ccccc}
\hline \multirow{2}{*}{ Kelas } & \multicolumn{2}{c}{ Teks Informasi } & \multicolumn{2}{c}{ Teks Fiksi } \\
\cline { 2 - 5 } & Sumber Lain & Karangan Sendiri & Sumber Lain & Karangan Sendiri \\
\hline I & - & - & $\left.2^{*}\right)$ & - \\
II & 1 & - & - & 1 \\
III & - & 1 & - & - \\
IV & 1 & - & 1 & - \\
V & 4 & - & - & - \\
VI & 2 & 3 & 2 & 2 \\
Total & 7 & 5 &
\end{tabular}

*) Cerita narasi diambil dari literacycloud.org (format cerita bergambar) dan diubah dalam bentuk teks fiksi.

Jumlah teks ini tidak termasuk jumlah soal, tetapi dari teks ini, guru mampu menyusun soal sebanyak dua hingga lima butir soal. Dari data ini, terlihat penggunaan teks informasi lebih banyak dari teks fiksi. Namun, Tabel 3 juga menyajikan hasil yang menarik di kolom karangan sendiri. Artinya, sebanyak lima teks adalah karangan sendiri. Teks karangan sendiri paling banyak dirancang oleh guru di kelas III, yaitu sebanyak tiga wacana, baik teks informasi maupun teks fiksi. Paparan ini selanjutnya menghadirkan satu fakta, yaitu banyak guru yang mengalami kesulitan dalam menyusun karangan sendiri sebagai stimulus soal, walaupun guru diberi kebebasan juga untuk mengambil referensi dari berbagai sumber (asalkan relevan dengan topik pembelajaran) semacam literacycloud.org (Kisno et al., 2021b), bobo.grid.id dan laman berita resmi tepercaya, seperti Kompas, Detik, Kumparan, Analisa, dan yang lainnya. Hasil ini terlihat dari tulisan karangan sendiri, baik berupa teks informasi maupun teks fiksi yang masih belum memenuhi kaidah Bahasa Indonesia (Gambar 4 dan Gambar 5). Kebanyakan teks yang disusun sendiri, secara aspek kebahasaan, memperlihatkan kalimat-kalimat yang tidak terhubung dengan rapi, dan paragraf-paragraf juga tidak kohesif satu sama lain.

Dari Gambar 4, konjungsi antar kalimat tidak ditemukan, padahal konjungsi memiliki fungsi untuk menghubungkan ide atau gagasan pada kalimat yang satu dengan kalimat ide atau gagasan pada kalimat yang lainnya (Melia, 2017). Di samping itu, penulisan teks ini juga tidak melalui kajian data yang aktual, sehingga ada informasi yang kurang sesuai dengan pengertian teks informasi sebelumnya, 
teks ini memuat data dan fakta. Jika kedua hal ini dikesampingkan, tentu teks menjadi misinformasi atau hoax. Jika teks demikian dijadikan stimulus soal, sudah pasti soal ini tidak valid, bahkan mungkin menimbulkan kebingungan bagi siswa ketika menjawabnya.

Di Indonesia, khususnya di Kalimantan, penebangan pohon sangat marak saat
ini.Contohnya penebangan pohon yang dilakukan oleh pihak tambang yang seenaknya
menebang pohon sembarangan tanpa menanamnya kembali.Dapat kita bayangkan yang
awalnya hutan Kalimantan sangat rimbun, kini sudah tinggal batang-batang, ranting-ranting
atau bahkan gundul sama sekali.Contoh lain dari penebangan pohon ialah banyaknya pohon
yang dipakai untuk kepentingan pribadi seperti membuat perusahaan buku,alat perabotan dan
lainnya.
Adapun dampak yang ditimbulkan ialah terjadinya banjir karena tidak ada pohon yang
menyerap kelebihan air, kegersangan karena tidak adanya penghasil oksigen dan penyerap
karbon dioksida, dan punahnya hewan-hewan akibat tidak ada tempat tinggal, lagi pula mereka
akan mencari makanan dan tempat dimana lagi? Otomatis mereka masuk ke kawasan tempat
tinggal penduduk sehingga meresahkan warga.

Gambar 4. Teks Informasi Karangan Guru

\footnotetext{
Siti siswa kelas 2 SD. Siti tinggal di kampung. Siti selalu mengerjakan tugas yang diberikan guru. Di rumah, Siti anak yang berbakti. Siti selalu membantu ayah dan ibu. Siti juga seorang anak yang rajin beribadah. Teman-teman Siti banyak yang berbeda agama. Mereka menjalankan ibadah masing-masing. Di lingkungan rumah, Siti memiliki banyak teman. Mereka sering bermain bersama.

Untuk menjawab soal nomor 1, Pilihlah salah satu jawaban yang benar !
}

1. Selain bermain bersama, contoh kegiatan yang bisa kita lakukan dengan teman yang berbeda agama adalah kecuali .
a. Beribadah bersama
b. Belajar bersama
c. Makan bersama

Gambar 5. Contoh Stimulan Teks Fiksi

Pada Gambar 5, secara aspek kebahasaan, penyusun tidak mampu membuat paragraf ini dengan baik. Pengulangan nama Siti terjadi berulang kali. Padahal, kata tersebut bisa digantikan dengan dia atau ia. Selain itu, penyusunan paragraf juga masih belum padu, sehingga paragraf pada Gambar 5 mengandung dua pokok pikiran berbeda, yaitu ciri karakter Siti dan teman Siti. Sebuah paragraf yang baik tentu hanya memiliki satu pokok pikiran utama, sehingga seyogianya paragraf ini bisa dipecah menjadi dua paragraf utama.

Dari sisi lainnya, soal tidak memiliki instruksi yang jelas atau tidak menghubungkan stimulus soal dengan pokok soal di nomor 1, padahal, teks tersebut adalah rujukan untuk menjawab, bukan malah terpisah masing-masing dan tidak berkaitan. Bahkan, soal yang disusun juga belum begitu baik karena salah satu pilihan jawaban tidak merujuk kepada wacana dan soal tidak mengutip nama Siti, tetapi menggunakan kita. Dengan demikian, siswa tidak perlu menelaah bacaan, hanya cukup mengingat dan memahami pertanyaan soal. Jika demikian, soal ini bukanlah ukuran soal level kognitif aplikasi, apalagi bernalar. Soal demikian termasuk kategori level mengingat dan memahami (LOTS).

Persoalan yang sama ini juga muncul pada banyak soal yang disusun oleh guru, yaitu sebanyak 28 butir dari total keseluruhan 55 butir soal termasuk dalam kategori ambigu (Tabel 4). Keambiguan soal muncul karena petunjuk soal yang tidak jelas, sehingga membingungkan peserta didik untuk menjawab, padahal soal tersebut sebenarnya merujuk kepada stimulus soal berupa teks. Gambar 6 berisi instruksi soal yang keliru. 
Tabel 4. Jumlah Kategori Soal Standar dan Soal Ambigu

\begin{tabular}{cccc}
\hline Kelas & Soal Standar & Soal Ambigu & Total \\
\hline I & 8 & 2 & 10 \\
II & 0 & 6 & 6 \\
III & 4 & 5 & 9 \\
IV & 5 & 3 & 8 \\
V & 1 & 8 & 9 \\
VI & 9 & 4 & 13 \\
Total & 27 & 28 & 55 \\
\hline
\end{tabular}

Berdasarkan wacana di atas, bacalah pernyataan di bawah ini! *

Benar Salah

Made dan Ipung berasal dari

keluarga yang berbeda,

sehingga Made sering

mengejek temannya yang

kurang mampu

Keberagaman ekonomi

dalam wacana di atas,

mengajarkan kita untuk

memiliki sikap peduli.

Dampak globalisasi secara

tidak langsung adalah ayah

Made telah membuka

lapangan kerja

Ayah Made lebih mencintai

produk luar negeri

Benar Salah

Gambar 6. Contoh Soal dengan Petunjuk Tidak Jelas

Untuk menjawab soal nomor. 4, dan 5, bacalah wacana berikut ini !

Keragaman di Lingkungan Kita
Keragaman merupakan ciri khas bangsa Indonesia. Keragaman dapat kita jumpai di mana saja, termasuk di lingkungan tempat tinggal kita. Keragaman yang sering kita jumpai

dalam kehidupan sehari-hari yaitu keragaman interaksi sosial. Manusia sebagai makhluk sosial tidak terlepas dari interaksi antarsesama.

Kita dapat berinteraksi dalam keberagaman dalam bentuk Kerja sama kelompok seperti kerja bakti di lingkungan masyarakat dan belajar kelompok dengan teman sekelas yang

berbeda suku, agama, maupun jenis kelamin.

4. Salah satu bentuk interaksi manusia dengan lingkungan alam adalah
a. Bercocok tanam di lahan subur
b. Membuat prakarya bunga
c. Bergaul dengan teman sebaya
d. Membuat kelompok ronda

5. Kegiatan berikut yang menunjukkan interaksi sosial adalah ......
a. Menonton televisi di rumah
b. Bermain game dalam ponsel
c. Membaca buku di perpustakaan
d. Berdiskusi dalam kelompok

Gambar 7. Contoh Soal yang Tidak Mengacu pada Stimulus Teks

Soal pada Gambar 6 muncul beberapa kali di beberapa tingkatan. Akan tetapi, hasil yang lebih mengejutkan adalah sebanyak 16 butir soal dari keseluruhan soal ambigu bermasalah dalam konstruksi soal. Soal yang disusun malah tidak mengacu kepada stimulus teks soal yang sudah disusun, sehingga 
untuk menjawab soal tersebut, siswa hanya perlu mengingat dan memahami materi di soal. Contoh soal demikian ditampilkan pada Gambar 7.

\section{Pembahasan}

Salah satu tujuan dari penelitian ini untuk memperoleh gambaran yang lebih jelas apakah sertifikasi berdampak positif terhadap kemampuan guru dalam menjawab soal literasi membaca. Sebagai tenaga pendidik, guru diwajibkan untuk memiliki pengakuan secara resmi akan kompetensinya agar dapat mengemban jabatan profesional. Sertifikasi guru merupakan suatu proses yang dijalani oleh guru agar ia dapat memperoleh pengakuan akan kompetensi yang dimilikinya dalam rangka melaksanakan pelayanan pendidikan pada satuan pendidikan tertentu (Permana, 2017).

Komponen kinerja guru merupakan salah satu faktor yang menyebabkan ada sertifikasi. Sebelum sertifikasi guru ada, kinerja guru tidak meningkat disebabkan oleh gaji yang rendah. Sertifikasi sudah berlangsung 10 tahun lebih dengan anggaran triliunan setiap tahun. Bahkan, pada tahun 2019 lalu, pemerintah sudah menggelontorkan dana lebih dari 60 triliun rupiah untuk tunjangan profesi guru negeri dan swasta.

Sertifikasi guru memiliki korelasi positif terhadap peningkatan kesejahteraan guru (Koswara \& Rasto, 2016). Namun demikian, berbagai kajian menunjukkan bahwa tunjangan profesi ini tidak berkorelasi positif terhadap peningkatan kualitas dari guru, khususnya pada komponen pelaksanaan pembelajaran dan pengembangan diri (Kartomo \& Slameto, 2016). Selain itu, pemberian tunjangan sertifikasi ternyata tidak memberikan dampak yang positif terhadap kinerja guru (Wahyuni, 2015).

Ketika membahas mengenai konten literasi membaca, teks sastra atau fiksi naratif merupakan karya imajinatif yang mengangkat persoalan-persoalan kehidupan manusia yang sudah dipadukan dengan imajinasi atau subjektivitas pengarang untuk kepentingan hiburan (Kementerian Pendidikan dan Kebudayaan, 2020a). Teks jenis ini berisi topik-topik sehari-hari yang mungkin sering bahkan pernah dihadapi oleh kebanyakan orang, sehingga guru lebih mudah memahaminya, apalagi cerita demikian sifatnya menghibur.

Hal ini sesuai dengan salah satu teori memahami bacaan, teori schema, yang menyebutkan pengetahuan seseorang sebelumnya bisa memudahkan seorang pembaca dalam membaca dan memahami sebuah teks (Pardede, 2008). Teori schemata sendiri merupakan teori dalam ilmu psikologi yang pertama kali dikemukakan oleh Sir Frederic Bartlett dan kemudian berkembang dan muncul pada teori perkembangan kognitif terkenal oleh Jean Piaget. Lalu, teori schemata ini digunakan oleh Anderson dalam mengkaji hubungannya dengan pemahaman membaca seseorang. Schemata menjadi penting bagi seorang pembaca dalam melakukan inferensi dan interpretasi terhadap teks yang dibaca (Anderson \& Pearson, 1984). Schemata diibaratkan sebagai kerangka dasar atau sebuah sistem konseptual di dalam diri seseorang dalam memproses informasi. Schemata bisa pula diartikan kerangka referensi untuk merekam berbagai peristiwa atau data (Sulistyaningsih, 2008)

Secara lebih sederhana, schemata ini dikenal sebagai background knowledge dalam proses memahami bacaan. Mengaktifkan background knowledge adalah salah satu strategi yang sangat penting dalam mengajarkan siswa literasi membaca. Ini diterapkan untuk membangun minat dan rasa ingin tahu mereka dalam memahami isi bacaan. Akan tetapi, seorang pembaca yang baik juga perlu paham bahwa setiap teks, baik teks fiksi maupun teks informasi, pasti memiliki struktur mikro dan makro. Pada level mikro, struktur teks dikenal sebagai pembentukan arti kata, klausa dan kalimat, sedangkan pada level makro, struktur ini mencakup arti paragraf, bagian terpenting dari paragraf ataupun keseluruhan isi wacana, dan termasuk juga struktur organisasi paragraf (Sulak \& Güneş, 2017). Ketika proses memahami bacaan dilakukan, seorang individu akan mendalami kedua struktur tersebut sambil menerapkan background knowledge ini.

Dalam tatanan struktur mikro dan makro sebuah teks, memahami teks informasi atau teks nonfiksi tentu akan lebih sulit, karena struktur teks informatif lebih abstrak dan kompleks (Aydemir et al., 2013). Secara definisi, teks informasi adalah teks yang ditulis berdasarkan data-data faktual, peristiwaperistiwa, dan sesuatu yang lain yang benar-benar ada dan terjadi dalam kehidupan. Data dan fakta dalam teks informasi dapat berupa data dan fakta kesejarahan, kemasyarakatan, dan keilmuan bidangbidang tertentu yang dapat dibuktikan kebenarannya secara empiris atau secara logika.

Kompleksitas teks demikian tersajikan dalam bentuk data dan fakta. Dalam memahaminya, pembaca harus mampu memahami struktur mikro dan makro teks tersebut sebelum mengintegrasikan, 
menafsirkan, mengevaluasi, bahkan merefleksikan isinya dengan background knowledge pembaca. Untuk mencapai level pemahaman teks informatif yang baik, tentu membutuhkan keterampilan membaca yang tidak biasa. Keterampilan ini hanya bisa diperoleh dari kebiasaan membaca teks informatif yang tinggi, sehingga background knowledge pembaca terbentuk sejak awal.

Hal ini tentu berkebalikan dengan masyarakat Indonesia. Riset World's Most Literate Nations Ranked tahun 2016 menyebutkan peringkat minat baca Indonesia berada di peringkat 60 dari 61 negara (Central Connecticut State University, 2016). Hal yang serupa juga disampaikan oleh UNESCO, yaitu hanya satu dari 1000 orang Indonesia yang rajin membaca (Devega, 2016.) Paparan data ini sungguh memprihatinkan dan menghadirkan pekerjaan rumah besar bagi pelaku pendidikan untuk meningkatkan literasi membaca para siswa, yang tidak lain harus dimulai dari guru sendiri, dengan cara rajin membaca.

Pelaksanaan Asesmen Literasi Membaca dan Numerasi memberikan paradigma baru bagi dunia pendidikan di Indonesia. Selama berpuluh tahun pendidikan kita terfokus kepada konten itu sendiri, sehingga tidak mengherankan apabila guru lebih banyak menjelaskan dalam setiap pelaksanaan pembelajaran, sementara siswa wajib banyak mendengarkan dan menguasai isi setiap pembelajaran dengan baik. Sebagai akibatnya, tidak mengherankan banyak siswa tidak mampu merefleksikan dan memanfaatkan isi tersebut dalam kehidupan nyata.

Pola pembelajaran ini tidak sesuai dengan jiwa dari AKM. Oleh sebab itu, penghapusan UN dan penerapan AN memulai babak baru di dalam mewujudkan Indonesia Maju 2045. Pembelajaran perlu mengintegrasikan kompetensi literasi membaca dan juga numerasi di setiap bidang studi. Kompetensi ini tidak bisa diukur dari sejauh mana siswa menguasai isi suatu mata pelajaran. Kompetensi ini erat berhubungan dengan kebiasan-kebiasaan membaca setiap hari. Misalnya, papan reklame yang bertuliskan diskon hingga 70\%. Pasti banyak kaum awam yang berpikir kalau diskon barangnya $70 \%$ dan ketka berada di toko tersebut, tak jarang mereka mungkin terkejut ternyata barang yang diskon $70 \%$ hanya produk tertentu saja, malah, kebanyakan barangnya diskon $20 \%, 30 \%$ atau $50 \%$. Ini membuktikan lemahnya kompetensi membaca karena tidak paham artinya, hingga dalam reklame tersebut.

Setiap orang pasti menghadapi contoh-contoh sejenis dengan ragam yang lebih kompleks dalam kehidupan nyata. Dengan demikian, siswa perlu dipersiapkan dan ditantang untuk bisa memecahkan persoalan hidup yang tidak pasti dengan cara memiliki kompetensi membaca yang baik. Perubahaan paradigma ini perlu diawali dalam kegiatan pembelajaran di ruang kelas oleh guru, yaitu menumbuhkan kompetensi membaca para siswa lewat pembelajaran bidang studi yang terintegrasi dengan literasi membaca. Namun, sebelum itu dilaksanakan, guru sendiri juga perlu menguji kemampuan mereka sendiri dalam menjawab soal literasi membaca. Di balik itu, guru juga turut menjadi pembelajar sebelum menyajikan pembelajaran demikian kepada siswa.

Evaluasi dari hasil penyusunan soal para guru membuktikan bahwa ternyata tidak semua guru yang sudah mampu menjawab soal literasi membaca dengan baik, pasti akan mampu menyusun soal literasi membaca dengan baik pula. Padahal, seluruh guru tematik adalah guru kelas yang hampir semuanya sudah berpengalaman mengajar lebih dari 10 tahun. Bahkan, hal yang lebih mengejutkan adalah delapan di antara mereka sudah lulus sertifikasi.

Pelaksanaan pembelajaran tidak terlepas dari motivasi dan kreativitas seorang guru. Sebagian guru yang sudah menerima tunjangan sertifikasi tidak menunjukkan motivasi yang lebih baik. Hal ini tentu saja berdampak pada kreativitas guru dalam melaksanakan pembelajaran. Dengan kata lain, motivasi dan kreativitas guru yang menerima tunjangan sertifikasi belum tentu lebih baik. Motivasi dan kreativitas muncul dari pengembangan diri, sehingga guru yang tetap nyaman dalam status quo, tidak akan mengalami peningkatan kualitas untuk mengembangkan diri. Pengembangan diri yang dimaksud dalam penelitian ini merupakan aktivitas-aktivitas yang bermanfaat untuk peningkatan kualitas diri guru yang dilakukan secara terus menerus, atau disebut juga continuous learning (Chanani \& Wibowo, 2019), misalnya dengan membaca artikel yang berhubungan dengan pelaksanaan pembelajaran, atau melakukan pembelajaran yang sangat relevan dengan masa kini, misalnya dengan menggunakan metode blended learning (Setiawan et al., 2019).

Selain itu, guru juga perlu menulis penelitian tindakan kelas atau penelitian lainnya yang berhubungan dengan peningkatan kualitas pembelajaran, menghadiri pelatihan atau lokakarya yang diselenggarakan oleh satuan pendidikan maupun di luar satuan pendidikan, serta menerapkan hal-hal yang baik dan positif dari hasil pelatihan maupun lokakarya yang diikuti. Demikian pula halnya dengan tunjangan sertifikasi, ternyata tidak menjamin peningkatan kualitas diri guru. Bila tunjangan tersebut di- 
gunakan untuk hal-hal yang tidak mendukung peningkatan kompetensi guru selain kesejahteraan, hal tersebut akan berdampak kurang baik. Sebaliknya, apabila tunjangan tersebut digunakan untuk membeli buku, membiayai publikasi hasil karya tulis, atau membeli perangkat pendukung pembelajaran lainnya, bukan tidak mungkin kualitas diri dan kualitas pembelajaran akan semakin meningkat.

Pelaksanaan pembelajaran oleh guru memiliki hubungan yang positif dengan kualitas pembelajaran yang dilaksanakan. Dengan adanya hubungan positif ini, hasil pembelajaran juga akan meningkat apabila pelaksanaan pembelajaran dilakukan menurut standar atau lebih baik dari yang sudah ditetapkan. Hal ini terlihat dari hasil skor PISA Indonesia yang cenderung menurun sejak keikutsertaan Indonesia sejak tahun 2012 pada literasi membaca, dan sejak tahun 2015 pada literasi numerasi. Sementara itu, AKM memiliki dua komponen asesmen, yakni literasi membaca dan literasi numerasi.

Temuan penelitian ini memperlihatkan betapa persoalan kualitas pendidikan sangat berpangkal dari guru sendiri sebagai motor penggerak perubahan. Kualitas tidak bisa hanya berupa gelar sarjana atau sertifikat pendidik yang sudah dimiliki puluhan tahun. Tetapi, itu ada pada diri guru sendiri yang mau senantiasa belajar seiring perubahan yang terus terjadi. Hal ini perlu dilenngkapi dengan peran penting kepala sekolah yang sangat diperlukan melalui kepedulian, kedisiplinan, semangat kerja, dan hubungan yang manusiawi untuk mewujudkan iklim kerja yang kondusif (Putri \& Wibowo, 2018).

Perubahan demi perubahan dalam kurikulum dan juga asesmen menuju kepada pendidikan berkualitas seharusnya disikapi dengan belajar sepanjang hayat, bukan malah keluhan atau hujatan. Padahal, kehidupan saat masa pandemi sudah menjungkalkan keraguan dan ketidakpercayaan guru dalam menerima penggunaan teknologi dalam pembelajaran. Sekarang, para guru tidak bisa menepis pentingnya penerapan teknologi dalam pembelajaran. Bukti lainnya juga menunjukkan kualitas guru bukan hanya sekadar pengalaman mengajar selama puluhan tahun. Selain itu, keterampilan mengerjakan soal literasi membaca guru perlu ditingkatkan, karena hal ini terkait kebiasaan dalam membaca. Guru yang mampu menjawab soal literasi membaca dengan baik belum tentu mampu menyusun soal literasi membaca dengan baik.

\section{SIMPULAN}

Di atas kertas, guru sertifikasi dianggap lebih unggul dengan kepemilikan sertifikat pendidik. Namun, ketika fokus utama pendidikan adalah kualitas, sertifikat dan keahlian atau keunggulan merupakan hal yang kompleks. Jika tidak dikembangkan secara berkesinambungan, keunggulan di masa lalu akan musnah seiring waktu. Oleh karena itu, guru non-sertifikasi perlu diberikan banyak kesempatan dan dimotivasi untuk belajar menambah dan meningkatkan ilmu dan keterampilan, sehingga pada waktunya tiba, mereka bisa menjadi penggerak perubahan. Sebanyak dua guru non-sertifikasi menunjukkan keterampilan yang lebih dalam mengerjakan soal literasi membaca. Mereka mungkin berpotensi untuk menyusun soal literasi membaca dengan baik.

Sementara itu, guru sertifikasi memang mau tidak mau dituntut untuk mengembangkan diri di masa pandemi Covid-19 yang sudah menghantam seluruh aspek kehidupan, termasuk pendidikan selama hampir 1 tahun. Teknologi yang semula ditolak dalam pembelajaran sekarang justru menghadirkan satu-satunya solusi ketika seluruh siswa belajar dari rumah dan guru mengajar dari rumah. Kondisi ini memaksa seluruh guru harus adaptif menyikapi perubahan demikian. Kemampuan adaptif ini perlu berlanjut dalam pembelajaran HOTS yang menjadi pondasi utama AKM. Pembelajaran yang mengedepankan penalaran tingkat tinggi yang hanya bisa dihadirkan dengan melibatkan siswa sebagai subjek pembelajaran. Mereka perlu ditantang oleh stimulan dari guru untuk mencari dan menemukan jawaban bukan malah guru lagi yang menjadi sumber jawaban itu sendiri.

Selanjutnya, masih banyak guru yang kesulitan untuk menyusun petunjuk menjawab soal dengan baik, sehingga menimbulkan petunjuk yang tidak jelas dan ambigu. Kemudian, mayoritas soal masih tersusun dalam level kompetensi menemukan informasi atau secara spesifik mengakses dan mencari informasi dalam teks. Oleh karena itu, variasi soal masih terbatas dalam level kognitif pertama dari tiga level kognitif yang dirancang oleh Kemdikbud. Beberapa guru tematik di tingkatan tertentu sudah berusaha untuk menyusun stimulus soal sendiri dalam bentuk teks fiksi maupun teks informasi. Namun, guru masih kesulitan menyusun paragraf atau kalimat yang kohesif satu sama lain. Akibatnya hubungan antar kalimat maupun paragraf menjadi tidak terpadu. Kemampuan guru mengerjakan soal literasi membaca tidak berarti guru akan mampu menerapkan pembelajaran yang terintegrasi dengan literasi membaca. 
Dengan demikian, persiapan AKM ini tidak cukup hanya meluruskan persepsi keliru akan AN dan AKM. Tidak pula hanya menjadi ajang cukup tahu AKM itu seperti apa. Melainkan, para pemangku kepentingan juga perlu meningkatkan kompetensi para guru dalam menghadapi AKM, seperti melaksanakan pembelajaran yang mengintegrasikan HOTS, dan juga menyusun soal dengan mengikuti kaidah standar HOTS. Kemampuan menyusun soal seharusnya tidak hanya bersumber dari Kemdikbud sendiri ataupun orang-orang tertentu di Dinas Pendidikan. Namun, guru di setiap sekolah juga perlu dibekali keahlian ini. Dengan demikian, program AKM bisa disukseskan oleh seluruh pelaku pendidikan dan tidak menjadi kontroversi di kemudian hari seperti yang terjadi pada UN selama bertahuntahun.

\section{DAFTAR PUSTAKA}

Anderson, R. C., \& Pearson, P. D. (1984). A schema-theoretic view of basic processes in reading. In P. D. Pearson (Ed.), Handbook of reading research (pp.255-291). Longman.

Aydemir, Z. I., Öztürk, E., \& Horzum, M. B. (2013). The effect of reading from screen on the 5th grade elementary students' level of reading comprehension on informative and narrative type of texts. Educational Sciences: Theory \& Practice, 13(4), 2272-2276. https://doi.org/10.12738/estp.2013.4.1294

Ayu, N. A., Suryanda, A., \& Dewi, R. (2018). Hubungan kebiasaan membaca dengan kemampuan literasi Sains siswa SMA di Jakarta Timur. BIOMA: Jurnal Ilmiah Biologi, 7(2), 161-171. https://doi.org/10.26877/bioma.v7i2.2804

Central Connecticut State University. (2016). World's most literate nations ranked. CCSU News Release. Retrieved from https://webcapp.ccsu.edu/?news=1767\&data

Chanani, U. L., \& Wibowo, U. B. (2019). A learning culture and continuous learning for a learning organization. International Conference on Meaningful Education ICMEd, 3(17), 591-598. https://doi.org/10.18502/kss.v3i17.4686

Cohen, L., Manion, L., \& Morrison, K. (2018). Research methods in education (8 ${ }^{\text {th }}$ ed.). Routledge.

Creswell, J. W., \& Creswell, J. D. (2018). Research design: Qualitative, quantitative, and mixed methods approaches. SAGE Publications, Inc.

Devega, E. (2016). Masyarakat Indonesia: Malas baca tapi cerewet di medsos. Kementerian Komunikasi dan Informatika. Retrieved from https://www.kominfo.go.id/content/detail/10862/teknologi-masyarakat-indonesia-malas-bacatapi-cerewet-di-medsos/0/sorotan_media

Kartomo, A. I., \& Slameto, S. (2016). Evaluasi kinerja guru bersertifikasi. Kelola: Jurnal Manajemen Pendidikan, 3(2), 219-229. https://doi.org/10.24246/j.jk.2016.v3.i2.p219-229

Kementerian Pendidikan dan Kebudayaan. (2019a). Panduan penilaian tes tertulis. Kementerian Pendidikan dan Kebudayaan.

Kementerian Pendidikan dan Kebudayaan. (2019b). Panduan penulisan soal HOTS. Kementerian Pendidikan dan Kebudayaan.

Kementerian Pendidikan dan Kebudayaan. (2020a). AKM dan Implikasinya dalam pembelajaran. Kementerian Pendidikan dan Kebudayaan.

Kementerian Pendidikan dan Kebudayaan. (2020b). Desain pengembangan soal AKM. Kementerian Pendidikan dan Kebudayaan.

Kementerian Pendidikan dan Kebudayaan. (2021). Gelar raker perdana, Kemendikbud dan DPR bahas program prioritas pendidikan 2021. Retrieved from https://www.kemdikbud.go.id/main/blog/2021/01/gelar-raker-perdana-kemendikbud-dan-dprbahas-program-prioritas-pendidikan-2021 
Kisno, K., Rokhyati, U., Fatimah, F. N., \& Siregar, R. M. (2021a). Teachers' misconception about national assessment and national examination. Ahmad Dahlan journal of English Studies, 8(1), 46-58. Retrieved from http://journal.uad.ac.id/index.php/ADJES/article/view/20081

Kisno, K., Siregar, V. M. M., Sirait, S., \& Winata, A. S. (2021b). Diseminasi Literacycloud untuk guru dan orangtua Sekolah Dasar Negeri Kecamatan Patumbak Deli Serdang dalam masa pandemi Covid-19. Publikasi Pendidikan: Jurnal Pemikiran, Penelitian dan Pengabdian Masyarakat Bidang Pendidikan, 11(1). 15-21. https://doi.org/10.26858/publikan.v11i1.18997

Koswara, K., \& Rasto, R. (2016). Kompetensi dan kinerja guru berdasarkan sertifikasi profesi. Jurnal Pendidikan Manajemen Perkantoran, 1(1), 61-71. https://doi.org/10.17509/jpm.v1i1.3269

Melia, M. (2017). Analisis penggunaan konjungsi Bahasa Indonesia pada editorial surat kabar Tribun Pontianak. Jurnal Pendidikan Bahasa, 6(2), 281-293. Retrieved from https://journal.ikippgriptk.ac.id/index.php/bahasa/article/view/676

Muta'ali, J. A. (2020). Opini masyarakat tentang asesmen nasional sebagai penganti ujian nasional. Universitas Pendidikan Indonesia.

Ningsih, A. W., Shara, A. M., Andriani, D., \& Kisno, K. (2021). Reading duration and financial literacy in Vocational High School Pematangsiantar. Jurnal Education and Development, 9(1), 577-583. https://doi.org/10.37081/ed.v9i1.2288

Novita, N., Mellyzar, M., \& Herizal, H. (2021). Asesmen Nasional (AN): Pengetahuan dan persepsi calon guru. Jurnal Ilmu Sosial dan Pendidikan, 5(1), 172-179. Retrieved from http://ejournal.mandalanursa.org/index.php/JISIP/article/view/1568

Pardede, P. (2008). A review on reading theories and its implication to the teaching of reading. Retrieved from https://parlindunganpardede.wordpress.com/articles/language-teaching/areview-on-reading-theories-and-its-implication-to-the-teaching-of-reading/

Permana, N. S. (2017). Peningkatan mutu tenaga pendidik dengan kompetensi dan sertifikasi guru. Studia Didaktika, 11(1), 1-8. Retrieved from http://103.20.188.221/index.php/studiadidaktika/article/view/513

Putri, N. H., \& Wibowo, U. B. (2018). Pengaruh kinerja kepala sekolah terhadap keberhasilan manajemen berbasis sekolah melalui partisipasi masyarakat di SMP. Jurnal Akuntabilitas Manajemen Pendidikan, 6(1), 45-59. https://doi.org/10.21831/amp.v6i1.9810

Setiawan, R., Mardapi, D., Pratama, A., \& Ramadan, S. (2019). Efektivitas blended learning dalam inovasi pendidikan era industri 4.0 pada mata kuliah teori tes klasik. Jurnal Inovasi Teknologi Pendidikan, 6(2), 148-157. https://doi.org/10.21831/jitp.v6i2.27259

Shara, A. M., Andriani, D., Ningsih, A. W., \& Shinoda, K. (2020). Correlating reading literacy and writing literacy in Junior High School Pematangsiantar. Journal of English Education, 5(2), 72-85. https://doi.org/10.31327/jee.v5i2.1249

Sulak, S. E., \& Güneş, F. (2017). The effects of teaching informative text through processual model on reading comprehension skills. International Electronic Journal of Elementary Education, 10(2), 265-271. Retrieved from https://www.iejee.com/index.php/IEJEE/article/view/338

Sulistyaningsih, L. S. (2008). Teori skema. Universitas Pendidikan Indonesia. Retrieved from http://file.upi.edu/Direktori/FPBS/JUR._PEND._BHS._DAN_SASTRA_INDONESIA/19601 2161986032-LILIS_ST._SULISTYANINGSIH/TEORI_SKEMA.pdf

Wahyuni, T. (2015). Sertifikasi guru tak jamin peningkatan mutu. CNN Indonesia. Retrieved from https://www.cnnindonesia.com/nasional/20150611154640-20-59410/sertifikasi-guru-takjamin-peningkatan-mutu 